\title{
0-081 当院を受診した伝染性単核球症症例の検討
}

○久保和彦 ${ }^{122}$ 、吉田崇正 ${ }^{1)}$ 、園田世里夏 ${ }^{2}$ 、中川尚志 ${ }^{2)}$

千鳥橋病院 耳鼻咽喉科 ${ }^{11}$ 、九州大学病院 耳鼻咽喉・頭頸部外科 ${ }^{2}$

伝染性単核球症（Infectious Mononucleosis；IM）は Epstein-Barr Virus(EBV) の初感染によって引き起こされる急性感 染症で、発熱、咽頭痛、頸部リンパ節腫脹、肝脾腫などを主徵とする疾患である。IM は高率に扁桃炎を併発するが、ペニ シリン系やセフェム系抗生物質を使用すると薬疹を誘発することが多々あることが知られており、扁桃炎を見た場合に抗生 片を使用する上で重要な鑑別診断である。生活環境の厳しい昨今では初回受診が救急外来であることもまれではなく、IM は扁桃炎に比べると罹患数が圧倒的に少ないため、初診時に咽頭所見だけで抗生剤を処方され、その後症状が軽快しない IM 患者が耳鼻咽喉科を受診し加療中に薬疹が出現して対応に苦渋することもある。IM と抗生剤の薬疹の関係は極めて有名 なので、ちまたに情報があふれている現代ではインシデント $3 a$ レベルを問われる可能性も否定できない。そのような背景 の中、当院を受診した IM 患者の臨床像を検討したため、文献的考察を踏まえて報告する。

\section{0-082＼cjkstart頭頸部癌治療中に血液培養で検出された真菌感染症の検討}

○浦口健介、小桜謙一、土井 彰、田村耕三

高知医療センター 耳鼻咽喉科

【はじめに】血管留置カテーテルや体内に埋め込んだ人工医療機器、悪性腫瘍、高侵襲手術後、広範囲な熱傷などの患者 は真菌感染症のハイリスクグループとされている。

【対象】2011年 6 月〜2018年 6 月の期間に当科で治療した頭頸部癌患者のうち血液培養で真菌が検出された症例を対象に した。

【方法】菌種、患者背景、臨床所見、治療内容について検討した。

【結果】血液培養で陽性となった真菌症例は 5 例あり、全例でCandida albicans であった。全例で皮下埋め込み型中心静 脈カテーテルを留置されていた。 $\beta-\mathrm{D}$ グルカン陽性であったのは 4 例あり、 1 例は $\beta-\mathrm{D}$ グルカンを未測定であった。真菌 性眼内炎は 5 例中 2 例に認め、 1 例に真菌性脊䯣炎を認めた。初回抗真菌薬は MCFG が 3 例、FLCZ が 2 例であった。カ テーテルは全例で抜去した。 5 例中 4 例は半年以内に腫瘍の進行により死亡した。

\section{0-083 当科における急性喉頭蓋炎症例の検討}

○野々村万智、白 康晴、吉澤 亮、岩永 健、藤原崇志、水田匡信、吉田充裕、佐藤進一、玉木久信 倉敷中央病院 耳鼻咽喉科・頭頸部外科

急性喉頭蓋炎は日常的にしばしば遭遇するが、急速に気道閉塞を引き起こし、死に至る危険性がある緊急性の高い疾患で ある。急性喉頭蓋炎の重症度の判断には、一般的に2005年にKatori らが提唱した分類が用いられている。しかし、実際の 診療においては発症から受診までの時間経過によっても臨床像が異なり、気道確保の適応を決定する際に判断に苦虑する場 面も多く、診断医の経験に依るところも大きいのが現状である。今回われわれは、2015年 1 月から 2018年10月までに当科を 受診した急性喉頭蓋炎60例を対象とし、検討を行った。男性34例、女性26例、年齢は11～94歳で平均年齢は54.6歳 18.9 歳。気道確保を行ったのは17例であり、うち 7 例で気管切開を行った。当科における急性喉頭蓋炎の治療例について、治療 選択の妥当性を検証するとともに気道確保の指標について文献的考察を加えて報告する。

\section{0-084＼cjkstart深頸部膿瘍から降下性壊死性縦隔炎へ至る危険因子は何か？}

才村朱里、宮本俊輔、山下 拓

北里大学病院 耳鼻咽喉科・頭頸部外科

媣頸部膿瘍は咽頭や歯科領域などの感染から頸部間隙に膿瘍を形成する疾患である。初期対応の遅れにより重篤な合併症 を来すため速やかな気道確保とドレナージが必要となる。高年齢や基礎疾患による免疫低下がある場合には症状の遷延や重 症化を来すことがあり注意が必要である。とりわけ降下性壊死性縦隔炎はまれではあるが深頸部の炎症が縦隔まで波及する 病態で致死的となることがある。早期の縦隔ドレナージを要するため迅速な発見・治療が重要である。

今回われわれは2009年 4 月から 2018 年 3 月の 10 年間に当科で手術加療を行った深頸部膿瘍84症例について臨床的検討を行 った。頸部外切開のみを要した70例と、降下性壊死性縦隔炎に波及した14例に分け、年齢・性別 ·感染源・基礎疾患・血液 検查所見・膿瘍形成部位・気管切開の有無・ドレナージ回数・検出菌・使用抗菌薬 · 入院期間 ·予後などにつき比較検討し た。深頸部膿瘍を重症化させ、降下性壊死性縦隔炎に波及させる因子について解析を行い報告する。 


\section{0-085＼cjkstart深頸部膿瘍の入院期間遷延に関連する要因}

○福家智仁、山田弘之、福喜多晃平、金児真美佳、澤 允洋、上田航毅、小林大介

伊勢赤十字病院＼cjkstart頭頸部・耳鼻咽喉科

くはじめに>深頸部膿瘍は喉頭浮腫など気道狭窄の可能性があり、切開排膿や気管切開など早急な対応が求められる。さ らに敗血症や、縦隔へ膿瘍が波及した場合にはさらに致命的となり、加療期間が長期化することもある。今回、当科にて深 頸部膿瘍に対して頸部外切開を要した手術症例の入院期間について検討した。

<対象 > 2012年 1 月から 2018 年 6 月までの 7 年 6 カ月の間に頸部外切開を要した深頸部膿瘍症例36例を対象とした。男性 21例、女性15例であり、平均年齢は67歳（17〜90歳）であった。

＜結果 $>25$ 例で気管切開を併施し、4 例で膿瘍残存や増悪のために再手術されていた。手術後退院までに要した期間は平 均34.4日（最短 3 日〜最長101日）であった。

く考察＞当科では頸部外切開でのドレナージを行った症例では、抗菌薬投与と共に、ヨードホルムガーゼの挿入、交換に よる処置を基本としている。軽症な症例に対して、気管切開を要した例や、縦隔進展例、術後誤舆のリスクが高く経口摂取 に時間を要した例では、入院期間が遷延する傾向があった。

\section{0-086 頸部リンパ節結核の検討}

○伊藤文展 ${ }^{122)}$ 、石川直明 ${ }^{1)}$ 、橋本陽介 ${ }^{11}$ 、遠藤理奈子 ${ }^{11}$ 、和佐野浩一郎1)、南 修司郎 ${ }^{12}$ 国立病院機構東京医療センター 耳鼻咽喉科 ${ }^{12}$ 、慶應義塾大学 医学部 耳鼻咽喉科 ${ }^{2}$

日本は依然結核の中蔓延国であり、耳鼻咽喉科医として結核は頸部リンパ節腫脹の鑑別すべき重要な疾患の一つである。 今回2018年 1 月から11月までの間に当科で頸部リンパ節結核と診断した 5 例について、診断までの経過や診断方法について 検討を行った。男性 2 例・女性 3 例、年齢は23歳〜88歳（中央值72歳）、主訴は全例頸部リンパ節腫脹であった。結核の既 往があった症例は 2 例、排菌のあった症例はなかった。初診科は耳鼻咽喉科 1 例・他科 4 例であり、他科から依頼された時 点で結核を疑われている症例はなかった。当科受診時から診断までに要した日数は13日〜128日（平均值68日）で、確定診 断に至った検体採取方法は、リンパ節穿刺 1 例・外切開による生検 4 例であった。臨床経過や画像所見は症例によりさまざ まである一方、全例でT-SPOT は陽性であった。T-SPOT は結核を見逃さないためにも有用なスクリーニング検査になり 得ることが示唆された。

\section{0-087ＩgG4 関連硬化性顎下腺炎（IgG4 SSS）における血清 IgG4 值（sIgG4）の経年的変化}

$\bigcirc$ 今野昭義 ${ }^{1}$ 、植木雄司 ${ }^{11}$ 、間多祐輔 ${ }^{1)}$ 、川瀬勝隆 ${ }^{12}$ 、牛来茂樹 ${ }^{122}$

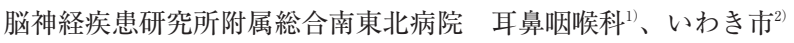

目的： $\mathrm{IgG}_{4} \mathrm{SSS}$ 15例を自然経過をみたA群 6 例（初診時平均 $\operatorname{sIgG}_{4} 271.2 \mathrm{mg} / \mathrm{dL}$ ）、両側顎下腺切除 B 群 5 例（平均 $\operatorname{sIgG}_{4}$ $544.8 \mathrm{mg}$ )、一側顎下腺切除 C 群 4 例（平均 $\mathrm{sIgG}_{4} 283.5 \mathrm{mg}$ ）に分け、さらにD群、非 $\operatorname{IgG}_{4} \mathrm{SSS}_{16}$ 例を含め、5〜12年間の $\mathrm{sIgG}_{4}$ の経年的変化と 2 次的な全身病変合併頻度を検討した。C 群 1 例、D 群 2 例を除き副腎皮質ホルモン処方はない。

結果： 5 年の経過で $\operatorname{sgG} G_{4}$ はA 群では 2 例を除き、またB 群では全例で低下し、B群の 2 例は 5 年、10年後に正常化し

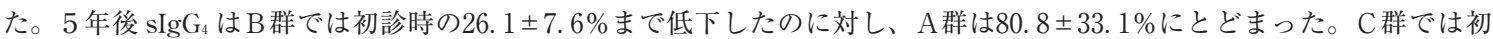
診時 $\operatorname{sIgG}_{4}$ 136 156mg の軽症 2 例が術後 $2 \sim 3$ 年で正常化したが、1 例で前立腺炎の合併による $\operatorname{sIgG}_{4}$ の急上昇を認めた。 またD群 2 例で二次的な $\mathrm{sIgG}_{4}$ 上昇と全身病変（後腹膜線維症による尿管狭窄と全身皮膚病変）合併を認めた。

\section{0-088 IgG4 関連疾患における顎下腺の線維化メカニズムの解析}

矢島諒人、垣内晃人、大和田 築、亀倉隆太、高野賢一 札幌医科大学 医学部 耳鼻咽喉科

今回われわれは IgG4-RD の特徴である高度線維化のメカニズムについて、顎下腺領域に着目し検討を行った。

IgG4-RD 患者の顎下腺組織より分離培養した線維芽細胞について遺伝子の網羅的発現解析を行ったところ、IL-6、IL18、TSLP、MMP1 で正常対照群に比して有意に発現の増加が認められた。これらについて免疫組織学的検討を行うと、い ずれも IgG4-RD 群の線維芽細胞に陽性像が認められた。

ここで IL-6 に着目したところ、IgG4-RD の線維芽細胞の IL-6 産生能は対照群より著しく充進しており、これは IL-1 $\beta$ 、 $\mathrm{TNF} \alpha 、 \mathrm{TGF}-\beta$ の処置により克進した。

さらに、ヒト肺線維芽細胞の増殖において IL-6 と共に重要な役割を担う WISP1 も IgG4-RD の培養線維芽細胞において 発現の増加がみられた。

また、培養線維芽細胞を IL-6、WISP1 それぞれで処置し、細胞周期を観察したところ、IgG4-RD、対照群いずれも G2/ $\mathrm{M}$ 期の増加が認められた。

以上の結果から IgG4-RD における高度の線維化は、炎症性サイトカインにより誘導された線維芽細胞産生の IL-6/ WISP1 を介した線維芽細胞の増殖によるものと考えられた。 